TAPROBANICA, ISSN 1800-427X. October, 2011. Vol. 03, No. 02: pp. 52-68.

(C) Taprobanica Private Limited, Jl. Kuricang 18 Gd.9 No.47, Ciputat 15412, Tangerang, Indonesia.

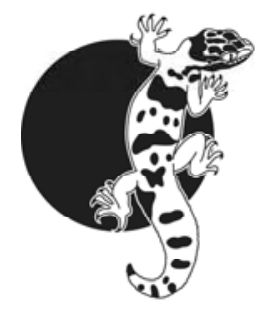

\title{
STATUS OF THE MAMMAL FAUNA IN SUNDARBAN TIGER RESERVE, WEST BENGAL - INDIA
}

Jayanta Kumar Mallick

Wildlife Wing, Forest Directorate, Bikash Bhawan, North Block, $3^{\text {rd }}$ floor, Salt Lake City, Kolkata, West Bengal, India Email: jayantamallick2007@rediffmail.com

\begin{abstract}
Sundarban Tiger Reserve $\left(2,584.89 \mathrm{~km}^{2}\right)$ in West Bengal is a part of the world's largest estuarine wetland and the only mangrove tigerland, spread over India and Bangladesh. Its plant associations exhibit a great generic/species diversity and offers habitats of many rare and endangered mammals. The dense thickets of Heritiera fomes, Nypa fruticans and Phoenix paludosa form the prime habitat of Panthera tigris tigris. This tigerland is also the abode of a good number of its prey and other associated mammal species. A one-year (January-December 2010) study was conducted with the frontline forest department staff to investigate the distribution and status of the mammalian species found in this thirty-eight years' old tiger conservation area, involving literature review, questionnaire and ground surveys. This has revealed shrinkage of the mangrove swamp habitat and a number of mammal species in decline due to extensive anthropogenic and natural threats. Out of forty nine extant species recorded (eight orders: twenty three families), four are globally endangered, four vulnerable and two near threatened as per IUCN Red List. Alarmingly, fifteen mammal species were found on only rare occasions. In addition, six species (two orders: three families) had become extinct during the last two centuries. Though distributed over all forest block areas, the frequency of tigersighting was recorded more from Sajnekhali Wildlife Sanctuary and the buffer areas than Sundarban National Park or the core area. High-priority wildlife conservation, proper implementation of the tiger action plan, further infrastructural development and effective joint forest management are essential for saving this tigerland.
\end{abstract}

Key words: Tigerland, world heritage, wetland, distribution, threats, conservation

\section{Introduction}

In 1947, the Radcliff Mission awarded the western Sundarbans (the Hooghly-Matla estuary) to West Bengal, India and the eastern Sundarbans to East
Bengal (now Bangladesh). The western Sundarbans in North and South 24-Parganas districts form about $40 \%$ of this largest estuarine wetland-cum- 
mangrove tigerland and 60\% falls in Bangladesh. Sundarban Tiger Reserve (STR) is located a little south of the Tropic of Cancer between $21^{\circ} 32^{\prime}-22^{\circ}$ $40^{\prime} \mathrm{N}$ and $88^{\circ} 05^{\prime}-88^{\circ} 10^{\prime} \mathrm{E}$. It is bounded by the rivers Kalindi, Raimangal and Harinbhanga on the east along the Bangladesh border, the rivers Bidya and Matla on the west, the Bay of Bengal on the south and the khals (erosion channels) Bara Herobhanga and Gomdi as well as the rivers Pitchkhali, Kapura, Korankhali, Raimangal and Kamlakhali on the north (Fig. 1). The surface area of STR is 2,584.89 $\mathrm{km}^{2}$, of which the forest cover is $1,680 \mathrm{~km}^{2}$ and $905 \mathrm{~km}^{2}$ is under water regime (Table 1).

$\begin{array}{lllll}4 & 0 & 4 & 8 & \text { Kilometers }\end{array}$

SCALE

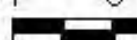

\section{LEGEND}

\begin{tabular}{l} 
CORE AREA \\
BUFFER AREA \\
RIVER WITATER \\
SWLS RANGE \\
DATTAR \\
DOBANKI \\
SAJNEKHALI \\
NATIONAL PARK(E) RANGE \\
BAGMARA \\
CHAMTA \\
NP(W') RANGE \\
$\square$ HALDIBARI \\
\hline NETIDHOPANI \\
BASIRHAT RANGE \\
$\square$ BAGNA \\
\hline HARINBHANGA \\
\hline JHING AKHALI \\
KHAT UAJHURI
\end{tabular}

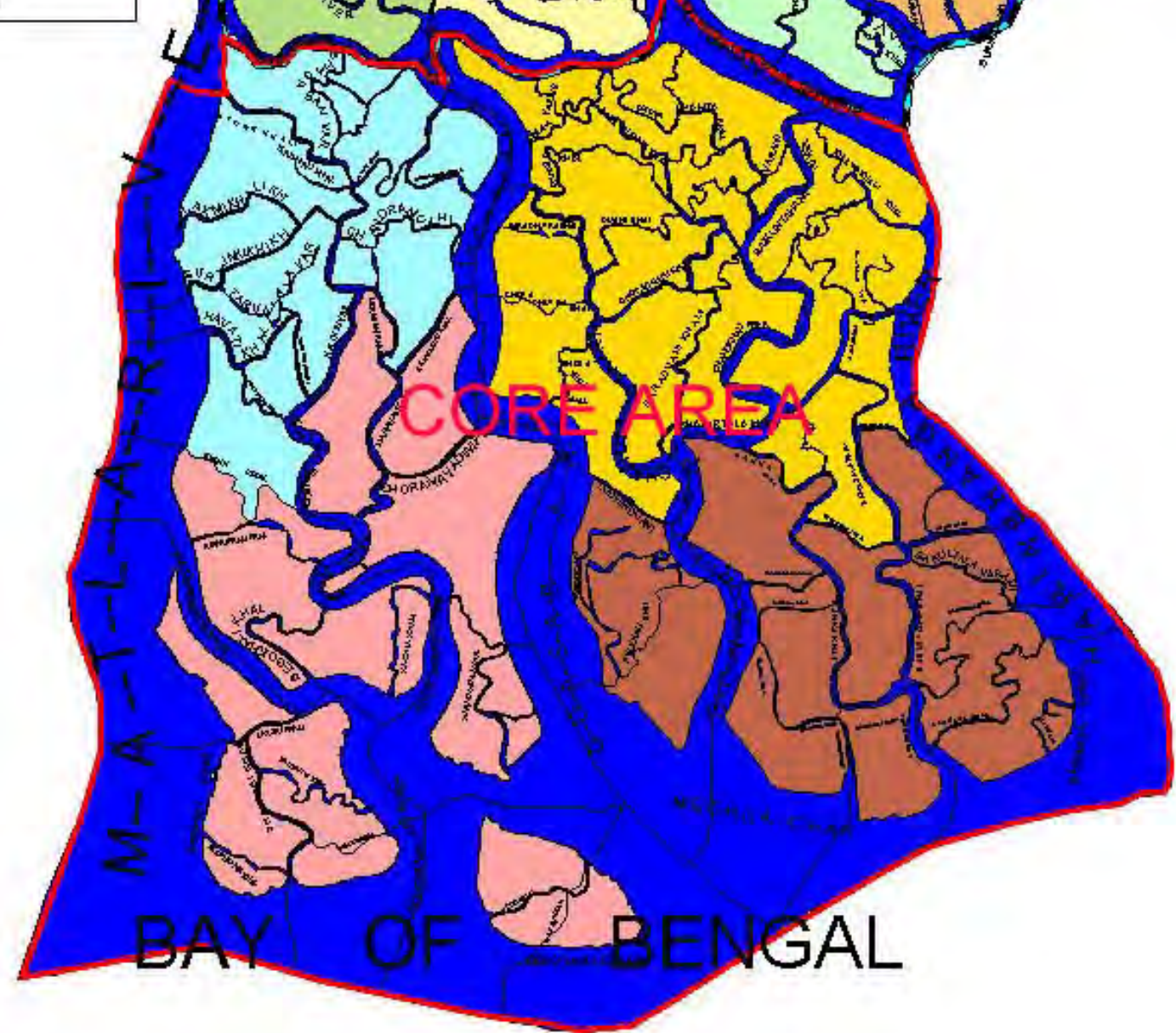

Fig.1: Location of the study area within the Ganges River estuary complex in the Bay of Bengal. 
Table 01: Blockwise distribution of the reserve forest in STR

\begin{tabular}{|l|r|r|r|r|}
\hline \multirow{2}{*}{ Block } & \multirow{2}{*}{ Compartments } & \multicolumn{3}{c|}{ Area (in hectares) } \\
\cline { 3 - 5 } & & \multicolumn{1}{c|}{ Land } & \multicolumn{1}{c|}{ Water } & \multicolumn{1}{c|}{ Total } \\
\hline Panchamukhani & $1-5$ & $13,946.77$ & $3,719.19$ & $17,665.96$ \\
\hline Pirkhali & $1-7$ & $13,684.52$ & $4,891.60$ & $18,576.12$ \\
\hline Matla & $1-4$ & $11,507.64$ & $6,122.30$ & $17,629.94$ \\
\hline Chamta & $1-8$ & $16,875.99$ & $5,192.70$ & $22,068.69$ \\
\hline Chhotohardi & $1-3$ & $9,260.75$ & $8,306.06$ & $17,566.81$ \\
\hline Goasaba & $1-4$ & $10,514.10$ & $6,658.93$ & $17,173.03$ \\
\hline Gona & $1-3$ & $8,562.64$ & $5,340.82$ & $13,903.46$ \\
\hline Bagmara & $1-8$ & $16,576.51$ & $12,816.84$ & $29,393.35$ \\
\hline Mayadwip & $1-5$ & $12,998.15$ & $14,338.11$ & $27,336.26$ \\
\hline Arbesi & $1-5$ & $9,663.83$ & $5,378.86$ & $15,042.69$ \\
\hline Jhilla & $1-5$ & $8,740.71$ & $3,573.09$ & $12,313.80$ \\
\hline Khatuajhuri & $1-3$ & $9,547.68$ & $3,693.69$ & $13,241.37$ \\
\hline Harinbhanga & $1-3$ & $8,391.04$ & $3,295.87$ & $11,686.91$ \\
\hline Netidhopani & $1-3$ & $6,447.68$ & $2,852.32$ & $9,300.00$ \\
\hline Chandkhali & $1-4$ & $11,293.15$ & $4,297.50$ & $15,590.65$ \\
\hline Total & & $\mathbf{1 , 6 8 , 0 1 1 . 1 6}$ & $\mathbf{9 0 , 4 7 7 . 8 8}$ & $\mathbf{2 , 5 8 , 4 8 9 . 0 4}$ \\
\hline
\end{tabular}

STR is a network of rivers, channels and creeks that forms innumerable flat islands, which are submerged mostly during the high spring tides and partially during the ordinary high tides. There are no villages within STR, but there is a $65 \mathrm{~km}$ forestvillage interface on the north-western side that is prone to frequent tiger-straying and livestock depredation (Vyas, 2004). The sources of all the rivers flowing through STR being progressively silted up, these are getting more brackish and shallow year after year. By repeated scouring during the ebb tides, innumerable small khals have been formed. Their banks are as high as two metres in some places, but shallow in the interior islands due to repeated silt deposits. The climate in STR is subtropical, where the temperature varies from 20 ${ }^{\circ} \mathrm{C}$ (December-January) to $33{ }^{\circ} \mathrm{C}$ (June-July), the average annual rainfall is $1,763 \mathrm{~mm}$ (75\% received during June to September) and the humidity level is $70-80 \%$. This region is often exposed to severe storms and cyclones.

STR is one of the foremost reserves of Project Tiger, which was launched in 1973 to save the Bengal tiger from extinction (Chaudhuri \& Chakrabarti, 1979d). In 1984, Sundarban National Park was declared with an area of $1,330.12 \mathrm{~km}^{2}$, which was also designated as the inviolate core area including the primitive zone or gene pool at Chamta block. In 1987, this park was recognized as a World Heritage Site (UNESCO) under Criterion IVHabitats of rare and endangered species. The Sundarban was also included in the World Network of Biosphere Reserve in 2001. The Government of
India has recommended the Sundarban as a Ramsar Site (a wetland of international importance). In 2007, an area of $1,699.62 \mathrm{~km}^{2}$ was notified as the Critical Tiger Habitat (CTH) by including additional area of $369.50 \mathrm{~km}^{2}$ (Reserve Forests) to the existing core. This CTH consists of nine blocks divided into forty two compartments: Matla (four), Chamta (eight), Chhotohardi (three), Goasaba (four), Gona (three), Bagmara (eight), Mayadwip (five), Netidhopani (three) and Chandkhali (four). The buffer zone of $885.27 \mathrm{~km}^{2}$ (as revised in 2009) includes six blocks (twenty nine compartments). Of these, Panchamukhani (five) and Pirkhali (seven) blocks form Sajnekhali Wildlife Sanctuary (362.42 $\mathrm{km}^{2}$ ), the gateway to this tigerland. The balance area in Arbesi (five), Jhilla (six), Khatuajhuri (three) and Harinbhanga (three) blocks is earmarked as a multiple-use zone for regulated harvest of various forest resources for meeting the local needs.

The study area is divided into four territorial ranges including six beats: Sajnekhali, Basirhat, East and West. STR is administered by the field director along with one deputy and two assistant directors. Besides, there are fifteen land-based and ten floating camps. Fourteen eco-development committees have been formed under Sajnekhali, Dattar and Bidya Beats and eleven forest protection committees under Bagna and Jhingakhali Beats, involving 8,158 members for the purpose of joint forest management and protection over $376.35 \mathrm{~km}^{2}$ in Arbesi, Jhilla, Pirkhali and Panchamukhani blocks. STR is recognized as one of the most important global biodiversity (aquatic and 
terrestrial) hot spots. It harbours about 350 species of vascular plants (26 true mangroves, 29 mangrove associates, 29 back mangroves, and 102 phytoplanktons, etc.) and there are 1692 recorded faunal species (481 vertebrates, 1 hemichordates, 1104 invertebrates and 106 protozoans) (Naskar \& Mandal, 1999; Raha \& Saha, 2004; Gopal \& Chauhan, 2006; Chaudhuri, 2007).

The Sundarban provides a number of ecological services such as (1) trapping of sediment and land formation, (2) protection of human lives and habitation from regular cyclones, (3) acting as a nursery for fish and other aquatic life, (4) oxygen production, (5) waste recycling, (6) production of timber, fuel wood and other minor forest products and (7) carbon recycling. This tidal halophytic mangrove reserve is especially important because there is no other protected area with more than 100 individuals of the Bengal tiger in the country. This compact habitat, divided into fifteen blocks of variable size (about $100-300 \mathrm{~km}^{2}$ ), is of sufficient size to maintain a viable population of the tiger. STR comes under 8B- East Coast Bio-geographic Zone and the Sunderbans Mangroves eco-region. The landscape characteristics of STR (Table 2) have been analysed recently (Jhala et al., 2008). The notified areas provide dense, almost impenetrable and inaccessible Tidal Swamp Forests (4B), sub-divided into Mangrove type (4B/TS1, 4B/TS2), Salt water type mixed forests (4B/TS3), Brackish type (4B/TS4) and Palm type (4B/E1) (Champion \& Seth, 1968).

Table 2: Landscape characteristics in STR (from Jhala et al., 2008)

\begin{tabular}{|l|r|}
\hline \multicolumn{1}{|c|}{ Parameters } & Value \\
\hline Number of forest patches & 737 \\
\hline Forest patch density per $1000 \mathrm{~km}^{2}$ & 12.3 \\
\hline Mean forest patch area $\left(\mathrm{km}^{2}\right)$ & 3.1 \\
\hline Mean forest perimeter to area ratio & 16.6 \\
\hline Total forest core area $\left(\mathrm{km}^{2}\right)$ & 534.4 \\
\hline Number of disjunct forest core areas & 128 \\
\hline Mean forest core area $\left(\mathrm{km}^{2}\right)$ & 0.72 \\
\hline Median forest core area $\left(\mathrm{km}^{2}\right)$ & 14.29 \\
\hline $\begin{array}{l}\text { Total forest core area in forest patches } \\
>\mathbf{1 0 0 0} \mathbf{~ k m}^{2}\end{array}$ & $\mathbf{5 3 4 . 4 2}$ \\
\hline
\end{tabular}

This fragile eco-system is sensitive to changes in salinity and the continuous cycle of erosion and deposition is affecting the plant communities, giving rise to a dynamic floristic changes. The northern boundary and new depositions are characterized by Kala Baen (Avicennia marina), Piara Baen (A. alba) and Sada Baen (A. officinalis), flanked by the foreshore grassland of Dhani grass (Oryza coarctata). These are gradually replaced by Genwa (Excoecaria agallocha) and then Goran (Ceriops decandra). The southern and eastern associates include Garjan (Rhizophora apiculata), Kankra (Bruguiera sexangula) and few patches of Sundari (Heritiera fomes). The pure Hental (Phoenix paludosa) forest exists in relatively high land with compact soil. Dhundul (Xylocarpus granatum), Passur (Xylocarpus mekongensis) and Golpata (Nypa fruticans) palm are extremely limited in extent. Keora (Sonneratia apetala), an indicator species for the newly accreted mud banks, is an important food resource for the herbivores. To date, no detailed study has been done to determine the mammalian diversity and status in this region. Although the frontline staff have gathered some knowledge and experience over years and maintain field records, few are published. Most of the studies in the western Sundarbans had dealt with the ecology, straying and man-eating behaviour of the tiger (Chakrabarti, 1979a, 1979b, 1980, 1984a, 1984b, 1984c, 1986, 1992 \& 1993b; Chakrabarti \& Chaudhuri, 1973, 1974, 1977, 1979, 1985 \& 1986; Chaudhury \& Chakrabarti, 1972, 1979a, 1979b, 1979c, 1980 \& 1989; Chaudhury \& Choudhury, 1994a \& 1994b; Chowdhury \& Sanyal, 1985a, 1985b \& 1985c; Das, 2002, 2003, 2005a, 2005b \& 2009; Dent, 1932; Deuti \& Roy Choudhury, 1999; Dwivedi, 2009; Ghosh \& Mandal, 1988; Gupta, 1966; Mukherjee, 1975 \& 2003; Mukherjee \& Tanti, 2001; Rishi, 1988, 1993a \& 1993b; Saha, 1988; Sanyal, 1981, 1983, 1987, 1990, 1992, 1993, 1998, 1999a, 1999b, 1999c \& 2001; Seidensticker et al., 1976). 30-40 species of mammals have been recorded in STR (Chaudhuri \& Sarkar, 2004, Das \& Nandi, 1999a \& 1999b; De, 1990; Ghosh, 1995; Mandal \& Nandi, 1989). Some species-specific studies were also done (Chakrabarti, 1993a; Chakrabarti \& De, 2007; Mandal, 1964, 1981 \& 1990; Mukherjee, 2006; Mukherjee \& Gupta, 1965; Rookmaaker, 1998). The recent landmark report (Jhala et al., 2008) estimated only 1411 adult tigers in India, which did not, however, include any population of the Sundarban tigers. To fill in the knowledge-gap, there is need of a detailed study on the current distribution and status of the Bengal tiger and other mammals in STR.

\section{Material and Methods}

After conducting a literature survey on the mammalian diversity in STR, a database was prepared for facilitating field verification during the study period (January-December 2010). A sample questionnaire survey was also conducted on a set 
pro forma among the fringe villagers, who depend on the forest resources for their livelihood, the frontline staff, researchers, tourist guides, representatives of local Eco-development/Forest Protection Committees and non-government organizations.

Working inside the hostile mangrove habitat, which is approachable and traversed only by the watercrafts, is very difficult due to inaccessibility, absence of any forest road, natural obstacles and lack of logistic infrastructures. The stiltroot/pneumatophore-infested and muddy forest floor prevents any transect survey. Hence, the field study was conducted with the help of the stationed and mobile forest department staff, who are engaged in regular patrolling and monitoring. A number of field visits ( $12 \times 3=36$ days) to the site were also made by the author.

Both up- and down-stream surveys were carried out by using a mechanized boat at a speed of 1.5-3 $\mathrm{km} / \mathrm{h}$ along the rivers and creeks from 5:30 h to 19:00 h. Observations were made from both the front and back of this vessel with a binocular. The boat-survey was, however, suspended at night due to poor visibility and security-risk. At night, the observations were made from the wire-caged watch towers at Sajnekhali, Sudhanyakhali, Dobanki, Netidhopani, Burirdabri, Jhingakhali, Gazikhali, Mayadwip, Gabbani, Arbesi-1 and Haldi by using a search light.

The mammal fauna were listed on the basis of direct sighting, indirect methods (e.g. foot prints, faeces, scratch marks, calls, etc.), questionnaire survey and departmental records (census, monitoring, casualty and rescue data). The mammal species sighted were identified and classified by consulting a current field handbook (Bahuguna \& Mallick, 2010).

Threats: The mangrove ecosystem is so fragile that any interference may lead to extinction of various components and also the ecosystem as a whole in the long run. Being the only forest in a region inhabited by 3.9 million people (2001 census), more than $5 \%$ of whom are estimated to enter forest for fishing, honey-collection, wood-cutting and shrimp fry-collection, the study area is prone to heavy biotic pressure. Between 1994-1995 and 20012002, ten tigers were poached while straying into the fringe villages. Though poaching of the tiger has been reduced, poaching of the prey species like the spotted deer and wild boar has led to prey- depletion. Although snaring is a traditional practice along with traps of different kinds, the spotted deer are also killed by gun-shot by following their track. The consumption of venison is largely local, but the actual impact of this problem is unknown. Deer meat and skin have been seized recently from the fringe villages like Samsernagar as well as the distant towns like Baruipur.

Besides, illicit felling of the small timber and fuel wood, unauthorized fishing, destruction of the spawns of various fish in the course of large-scale catching of the tiger prawn (Peanacus monodon) spawns, are reportedly high in the buffer zone because of rapid increase in the human population, poverty and unemployment in the reclaimed areas. All these have adverse effect on the ecological balance, leading to elimination of the floral and faunal species.

Often the Sundarban suffers from severe storms and cyclones. During the super cyclone Aila (May 2009), the frontline shelter vegetation was damaged severely in some vulnerable areas. Many deer were swept away to the fringe villages and, in some cases, the villagers captured them and handed over to the forest staff, but some might have been poached by the distressed people for consumption (Banerjee, 2009). Except one case of tiger-straying into a fringe village, there was no report of any tiger's death during the study period. Inasmuch as the wild islanders are excellent swimmers and possibly warned of the incoming natural calamity in advance, most of them could escape and perhaps took refuge in the unaffected highlands with dense vegetation.

The reduced freshwater flow from the Ganges and its distributaries and increase in salinity (range varying from $0.4 \%$ to $27.5 \%$ ) of the water and soil has caused floristic changes and shrinkage of the tiger's prime habitat, i.e. Sundari (Heritiera fomes), Hental (Phoenix paludosa) and Golpata (Nypa fruticans). Gradual sinking of the delta due to rising sea levels is also reported. The islands or sandbars like Bedford (Suparibhanga), Kabasgadi, Lohachara (in river Hooghly) and New Moore /South Talpatti, $2 \mathrm{~km}$ from river Harinbhanga, have already disappeared and the Ghoramara Island $\left(80 \mathrm{~km}^{2}\right)$ has submerged. Water pollution sources include the exhaust oil from the watercrafts, sewage and chemical effluents upstream. Soil erosion and silt deposition, uncontrolled tourism (about one hundred thousand people visiting the Sundarbans every year), straying of tigers from seven forest 
blocks, viz. Pirkhali, Panchamukhani, Arbesi, Jhilla, Chandkhali, Goasaba and Harinbhanga into the fringe villages (21 villages mostly affected) and depredation on the domestic animals, killing of human beings entering the forests by the tigers and the porous international border (about $20 \mathrm{~km}$ ) with Bangladesh are some of the serious management problems in STR. Moreover, there are organizational (frontline staff) and infrastructure deficiencies. Project Tiger Directorate assessed that comparatively an extensive area is covered by a staff in the Sundarban- Ranger $215.42 \mathrm{~km}^{2}$, Forester $112.39 \mathrm{~km}^{2}$ and Guard $25.34 \mathrm{~km}^{2}$ (GOI, 2005).

\section{Results and Discussion}

Forty nine extant species (eight orders: twenty three families) were recorded during the present study, out of which four are globally endangered, four vulnerable and two near threatened as per IUCN Red List and, alarmingly, 20 mammal species (40.81\%) were found only rarely (Table 3). Fifteen species are, however, included in Schedules I and II of the Indian Wildlife (Protection) Act, 1972. Besides, six species (two orders: three families) were extinct during last two centuries due to habitat degradation and ecological changes (Table 4).

Table 3: Checklist and status of extant mammalian species in STR (C: common, R: rare, EN: endangered, VU: vulnerable, NT: near threatened, LC: least concern, DD: data deficient)

\begin{tabular}{|c|c|c|c|c|}
\hline No. & Species name & Common name & $\begin{array}{l}\text { Local } \\
\text { status }\end{array}$ & IUCN \\
\hline \multicolumn{5}{|c|}{$\begin{array}{c}\text { Order SORICOMORPHA Shrew-form } \\
\text { Family SORICIDAE Shrews }\end{array}$} \\
\hline 01 & Suncus murinus Linnaeus, 1766 & White-tailed musk shrew & $\mathrm{C}$ & LC \\
\hline \multicolumn{5}{|c|}{ Order CHIROPTERA Bats } \\
\hline 02 & Rousettus leschenaulti Desmarest, 1820 & Indian fulvous fruit bat & $\mathrm{C}$ & LC \\
\hline 03 & Cynopterus sphinx Vahl, 1797 & Greater short-nosed fruit bat & $\mathrm{C}$ & LC \\
\hline 04 & Pteropus giganteus Brünnich, 1782 & Indian flying fox & $\mathrm{C}$ & LC \\
\hline \multicolumn{5}{|c|}{ Family MEGADERMATIDAE False vampire bats } \\
\hline 05 & Megaderma lyra Geoffroy, 1810 & Greater false vampire bat & $\mathrm{C}$ & LC \\
\hline 06 & Megaderma spasma Linnaeus, 1758 & Lesser false vampire bat & $\mathrm{R}$ & LC \\
\hline \multicolumn{5}{|c|}{ Family RHINOLOPHIDAE Rhinolophids } \\
\hline 07 & Coelops frithi Blyth, 1848 & Tailless leaf-nosed bat & $\mathrm{R}$ & LC \\
\hline 08 & Hipposideros bicolor Temminck, 1834 & Bicoloured round- leaf bat & $\mathrm{R}$ & LC \\
\hline 09 & Hipposideros lankadiva Kelaart, 1850 & Kelaart's gigantic leaf-nosed bat & $\mathrm{R}$ & LC \\
\hline 10 & Rhinolophus lepidus Blyth, 1844 & Little Indian horseshoe bat & $\mathrm{C}$ & LC \\
\hline \multicolumn{5}{|c|}{ Family RHINOPOMATIDAE Mouse-tailed bats } \\
\hline 11 & Rhinopoma hardwickii Gray, 1831 & Lesser mouse-tailed bat & $\mathrm{R}$ & LC \\
\hline \multicolumn{5}{|c|}{ Family EMBALLONURIDAE Sheath-tailed bats } \\
\hline 12 & Taphozous longimanus Hardwicke, 1825 & Long-armed sheath-tailed bat & $\mathrm{C}$ & LC \\
\hline \multicolumn{5}{|c|}{ Family VESPERTILIONIDAE Evening bats } \\
\hline 13 & Myotis hasseltii Temminck, 1840 & Van Hasselt's bat & $\mathrm{R}$ & LC \\
\hline 14 & Pipistrellus coromandra Gray, 1838 & Indian Pipistrelle & $\mathrm{C}$ & LC \\
\hline 15 & Pipistrellus mimus Wroughton, 1899 & Indian pygmy pipistrelle & $\mathrm{C}$ & LC \\
\hline 16 & Scotophilus kuhli Leach, 1821 & Lesser yellow house bat & $\mathrm{C}$ & LC \\
\hline 17 & Scotophilus heathi Horsfield, 1831 & Asiatic lesser yellow bat & $\mathrm{R}$ & LC \\
\hline 18 & Kerivoula papillosa Temminck, 1840 & Papillose woolly bat & $\mathrm{R}$ & LC \\
\hline \multicolumn{5}{|c|}{$\begin{array}{l}\text { Order PRIMATES Primates } \\
\text { Family CERCOPITHECIDAE Monkeys }\end{array}$} \\
\hline 19 & Macaca mulatta Zimmermann, 1780 & Rhesus macaque & $\mathrm{C}$ & LC \\
\hline \multicolumn{5}{|c|}{$\begin{array}{c}\text { Order CARNIVORA } \\
\text { Family CANIDAE Dogs }\end{array}$} \\
\hline 20 & Canis aureus Linnaeus, 1758 & Golden jackal & $\mathrm{C}$ & LC \\
\hline 21 & Vulpes bengalensis Shaw, 1800 & Bengal fox & $\mathrm{R}$ & LC \\
\hline
\end{tabular}


22 Felis chaus Schreber, 1777

23 Prionailurus bengalensis Kerr, 1792

24 Prionailurus viverrinus Bennett, 1833

25 Panthera tigris Linnaeus, 1758

\section{Family HERPESTIDAE Mongooses}

26 Herpestes edwardsi Saint-Hilaire, 1818

27

Herpestes javanicus Saint-Hilaire, 1818
Family FELIDAE Cats

Jungle cat

Leopard cat

Fishing cat

Bengal tiger

$$
\begin{array}{l|l}
\mathrm{C} & \mathrm{LC} \\
\mathrm{R} & \mathrm{LC} \\
\mathrm{R} & \mathrm{EN} \\
\mathrm{C} & \mathrm{EN}
\end{array}
$$

Common or grey mongoose

Small Indian mongoose

Family MUSTELIDAE Otters

28 Lutrogale perspicillata Saint-Hilaire, $1826 \quad$ Smooth-coated otter

29 Aonyx cinerea Illiger, 1815

Small-clawed otter

$$
\begin{array}{l|l}
\mathrm{R} & \mathrm{VU} \\
\mathrm{C} & \mathrm{VU}
\end{array}
$$

Family VIVERRIDAE Civets

\begin{tabular}{l|l|l|c|c}
30 & Paradoxurus hermaphroditus Pallas, 1777 & Common palm civet & C & LC \\
31 & Viverra zibetha Linnaeus, 1758 & Large Indian civet & R & NT \\
32 & Viverricula indica Saint-Hilaire, 1803 & Small Indian civet & C & LC
\end{tabular}

\section{Orcaella brevirostris Gray, 1866 \\ 34 Sousa chinensis Osbeck, 1765 \\ 35 Stenella attenuata Gray, 1846}

Viver ricula indica Saint-Hilaire, 1803

Order CETACEA Dolphins and Porpoises

Family DELPHINIDAE Dolphins

Irrawaddy dolphin
Indo-Pacific hump-backed dolphin
Pantropical spotted dolphin

$$
\begin{array}{l|l}
\mathrm{C} & \mathrm{VU} \\
\mathrm{R} & \mathrm{NT} \\
\mathrm{R} & \mathrm{LC}
\end{array}
$$

Pantropical spotted dolphin

Family PHOCOENIDAE Porpoises

\begin{tabular}{l|l|l|l|l}
36 & Neophocaena phocaenoides Cuvier, 1829 & Little black finless porpoise & R & VU
\end{tabular}

Family PLATANISTIDAE

$37 \quad$ Platanista gangetica Roxburgh, 1801

Gangetic dolphin

C $\quad$ EN

Order ARTIODACTYLA Even-toed ungulates

Family SUIDAE Pigs

38 | Sus scrofa Linnaeus, 1758

Wild boar

Family CERVIDAE Deer

39 Axis axis Erxleben, 1777

Cheetal or Spotted deer

\begin{tabular}{l|l} 
C & LC
\end{tabular}

Order PHOLIDOTA

Family Manidae

$40 \quad$ Manis pentadactyla Linnaeus, 1758

Chinese pangolin

\begin{tabular}{l|l}
$\mathrm{R}$ & $\mathrm{EN}$
\end{tabular}

Order RODENTIA Rodents

Family SCIURIDAE Squirrels

\begin{tabular}{l|l|l}
41 & Funambulus pennantii Wroughton, 1905 & Five-striped palm squirrel
\end{tabular}

Family MURIDAE Rats, Mice

\begin{tabular}{l|l|l|c|c}
42 & Bandicota bengalensis Gray \& Hardwicke, 1833 & Indian mole rat & C & LC \\
43 & Bandicota indica Bechstein, 1800 & Large bandicoot rat & C & LC \\
\hline 44 & Mus booduga Gray, 1837 & Little Indian field mouse & C & LC \\
45 & Mus musculus Linnaeus, 1758 & House mouse & C & LC \\
46 & Rattus norvegicus Berkenhout, 1769 & Brown Norway rat & R & LC \\
47 & Rattus rattus Linnaeus, 1758 & Common black house rat & C & LC
\end{tabular}

\begin{tabular}{l|l|l}
48 & Hystrix indica Kerr, 1792 & Indian crested porcu \\
& Order LAGOMORPHA Hares
\end{tabular}

Family HYSTRICIDAE Porcupines

Family LEPORIDAE Hares

49 Lepus nigricollis Cuvier, 1823 Indian rufous-tailed or black-naped hare LC 
Table 4: List of extinct mammalian species in the study area

\begin{tabular}{|c|c|c|c|}
\hline No. & Species name & Common name & Remarks \\
\hline \multicolumn{4}{|c|}{$\begin{array}{c}\text { Order PERISSODACTYLA Odd-toed ungulates } \\
\text { Family RHINOCEROTIDAE Rhinoceros }\end{array}$} \\
\hline 01 & Rhinoceros unicornis Linnaeus, 1758 & $\begin{array}{l}\text { Great Indian one- } \\
\text { horned rhinoceros }\end{array}$ & $\begin{array}{l}\text { Changing landscape and loss of freshwater } \\
\text { mangroves led to extinction of this species. }\end{array}$ \\
\hline 02 & Rhinoceros sondaicus Desmarest, 1822 & $\begin{array}{l}\text { Smaller one-horned } \\
\text { or Javan rhinoceros }\end{array}$ & $\begin{array}{l}\text { Last one killed around 1888; presence } \\
\text { during early } 20^{\text {th }} \text { century doubtful. Remains } \\
\text { of this animal were collected from an } \\
\text { excavated pond in upper layers in } 1870 \text { and } \\
\text { displayed in the Indian Museum, Kolkata. }\end{array}$ \\
\hline \multicolumn{4}{|c|}{$\begin{array}{l}\text { Order ARTIODACTYLA Even-toed ungulates } \\
\text { Family CERVIDAE Deer }\end{array}$} \\
\hline 03 & Rucervus duvaucelii Cuvier, 1823 & $\begin{array}{c}\text { Swamp deer or } \\
\text { Barasingha }\end{array}$ & $\begin{array}{l}\text { Existed till the earlier part of the } 20^{\text {th }} \\
\text { century. }\end{array}$ \\
\hline 04 & Muntiacus muntjak Zimmermann, 1780 & Barking deer & $\begin{array}{l}\text { During early } 20^{\text {th }} \text { century represented about } \\
4 \% \text { of total deer population in the } \\
\text { freshwater mangrove forests, which were } \\
\text { reclaimed; even hoof-marks were not } \\
\text { recorded within Tiger Reserve in recent } \\
\text { past. }\end{array}$ \\
\hline 05 & Axis porcinus Zimmermann, 1780 & Hog deer & Extinct at the end of $19^{\text {th }}$ century. \\
\hline \multicolumn{4}{|c|}{ Family BOVIDAE Buffaloes } \\
\hline 06 & Bubalus bubalis Linnaeus, 1758 & $\begin{array}{l}\text { Asiatic wild water } \\
\text { buffalo }\end{array}$ & $\begin{array}{l}\text { Found till 1885; by the end of } 19^{\text {th }} \text { century } \\
\text { died out. A specimen of hip bone found } \\
\text { from a pond excavation during } 1980 \text { was } \\
\text { identified by Zoological Survey of India. }\end{array}$ \\
\hline
\end{tabular}

Apart from the tiger, there are no other large terrestrial carnivores in the Sundarbans. The small carnivore community is composed of the leopard cat (Prionailurus bengalensis), fishing cat (Prionailurus viverrinus) and jungle cat (Felis chaus). The creeks fringing the mangroves and associated mudflats harbour the diurnal smooth Indian otter (Lutra perspicillata) and the nocturnal small-clawed otter (Aonyx cinereus), which live on the fishes, crustaceans and mollusks. The jackal (Canis aureus) and Indian fox (Vulpes bengalensis) are present in the fringe areas. Among the civets, the small Indian civet (Viverricula indica) is common in the reclaimed lands along with the palm civet (Paradoxurus hermaphrodites), which is seen occasionally. At present, the main ungulate prey species in STR are the cheetal (Axis axis), which are found in small and large herds, and the wild boar (Sus scrofa), only loners of which are sighted. The Great one-horned rhinoceros (Rhinoceros unicornis), small one-horned rhinoceros $(R$. sondaicus), barking deer (Muntiacus muntjak), swamp deer (Cervus duvauceli), hog deer (Axis porcinus) and wild buffalo (Bubalus bubalis) are already extinct (Bahuguna \& Mallick, 2004; Mukherjee, 1980). During early 1990s, Project
Tiger estimated the populations of the cheetal $(31,000)$, wild boar $(12,000)$ and rhesus macaque $(38,000)$. Rhesus macaque (Macaca mulatta), the only primate in the Sundarbans, is quite abundant. They are gregarious and found in scattered groups of 30-40 individuals. At Sudhanyakhali, this monkey is abundant seasonally and its numbers generally decline after April, when most of them migrate to the interior forests, and increase from October onwards with the start of the tourist season. Their mating season is usually between February and July.

The rivers and near-shore waters are the abode of five aquatic mammals: the dolphins and porpoises. Among them, the Gangetic dolphin (Platanista gangetica) and Irrawady dolphin (Orcaella brevirostris) are common along the upper part of the rivers Matla, Bidyadhari, the confluence of Raimangal and Jhilla at Bagna, Amlamati and at Sudhanyakhali. Rarely, the black finless porpoise (Neomeris phocoenoides) is met with. An IndoPacific hump-backed dolphin was sighted and photographed a few years back near Sajnekhali. There are no recent records of sighting any Pantropical spotted dolphin in the Sundarban. 
Among the rodents, Bandicota indica, $B$. bengalensis and Mus booduga are quite abundant. The white-bellied tree rats (Rattus rattus arboreus Horsfield, 1851), nesting in bunches of leaves and twigs, were also observed. Holes and nests of the five-striped palm squirrel (Funambulus pennantii) in the tree trunks and branches were also discovered.

All the previous censuses (1976-2004) in STR recorded a population of \pm 250 tigers on the basis of pugmark analysis (Table 5). Block-wise abundance of the tiger in 2004 census was also assessed (Table 6). Accordingly, tiger concentration was calculated to be $<10 \mathrm{~km}^{2} /$ tiger. Since 2006, a new methodology- "Monitoring of tigers, co-predators, prey and habitat" through direct sighting, collection of pugmarks and scats, roaring and other signswas introduced in Sundarbans. Data were available during 2007-2008 (Table 7) and 2008-2009 (Table 8).

Table 5: Tiger census (plaster cast method) in STR

\begin{tabular}{|c|c|c|c|c|}
\hline Year & Male & Female & Cub & Total \\
\hline 1973 & \multicolumn{3}{|c|}{ Incomplete census, only one-fifth } & 50 \\
\hline 1976 & 66 & 72 & 43 & 181 \\
\hline 1977 & - & - & - & 205 \\
\hline 1983 & 137 & 115 & 12 & 264 \\
\hline 1989 & 126 & 109 & 34 & 269 \\
\hline 1992 & 92 & 132 & 27 & 251 \\
\hline 1996 & 95 & 126 & 21 & 242 \\
\hline 1997 & 99 & 137 & 27 & 263 \\
\hline 1999 & 96 & 131 & 27 & 254 \\
\hline 2001 & 93 & 129 & 23 & 245 \\
\hline 2004 & 83 & 133 & 33 & 249 \\
\hline
\end{tabular}

Table 6: Block-wise census figures (2004) in STR

\begin{tabular}{|l|c|c|c|c|}
\hline Block (compartment) & Male & Female & Cubs & Total \\
\hline Pirkhali (1-7) & 8 & 14 & 5 & 27 \\
\hline Panchamukhani (1-5) & 6 & 13 & 4 & 23 \\
\hline Jhilla (1-6) & 3 & 5 & - & 8 \\
\hline Arbesi (1-5) & 8 & 12 & 1 & 21 \\
\hline Harinbhanga (1-3) & 4 & 6 & 3 & 13 \\
\hline Khatuajhuri (1-3) & 3 & 6 & 3 & 12 \\
\hline Champta (1-8) & 11 & 12 & 3 & 26 \\
\hline Chandkhali (1-4) & 5 & 9 & - & 14 \\
\hline Bagmara (1-8) & 11 & 13 & 3 & 27 \\
\hline Gona (1-3) & 4 & 6 & 2 & 12 \\
\hline Netidhopani (1-3) & 3 & 5 & 1 & 9 \\
\hline Chhotohardi (1-3) & 3 & 10 & 2 & 15 \\
\hline Matla (1-4) & 6 & 8 & 2 & 16 \\
\hline Goasaba (1-4) & 4 & 8 & 2 & 14 \\
\hline Mayadweep (1-5) & 4 & 6 & 2 & 12 \\
\hline Total & 83 & 133 & 33 & 249 \\
\hline
\end{tabular}

Table 7: Month-wise tiger monitoring data in STR during 2007-2008

\begin{tabular}{|l|c|c|c|c|c|}
\hline \multirow{2}{*}{ Month } & \multicolumn{2}{|c|}{$\begin{array}{c}\text { Direct tiger } \\
\text { sighting (no) }\end{array}$} & $\begin{array}{c}\text { Roaring } \\
\text { heard } \\
\text { (no) }\end{array}$ & \multicolumn{2}{c|}{$\begin{array}{c}\text { Sighting of } \\
\text { fresh } \\
\text { pugmarks } \\
\text { (no) }\end{array}$} \\
\cline { 2 - 6 } & Adult & Cub & & Adult & Cub \\
\hline April & 25 & - & 10 & 586 & 3 \\
\hline May & 14 & - & 8 & 629 & - \\
\hline June & 11 & 4 & 6 & 411 & - \\
\hline July & 13 & - & 5 & 380 & - \\
\hline August & 21 & - & 19 & 433 & 5 \\
\hline September & 24 & - & 19 & 332 & 1 \\
\hline October & 18 & - & 12 & 466 & 1 \\
\hline November & 26 & - & 17 & 455 & - \\
\hline December & 27 & 1 & 15 & 747 & - \\
\hline January & 28 & 1 & 22 & 849 & - \\
\hline February & 25 & - & 17 & 711 & - \\
\hline March & 35 & - & 6 & 540 & - \\
\hline Total & 267 & 6 & 156 & 6539 & 10 \\
\hline
\end{tabular}

Table 8: Month-wise tiger monitoring data in STR during 2008-2009

\begin{tabular}{|l|c|c|c|c|c|}
\hline \multirow{2}{*}{ Month } & \multicolumn{2}{|c|}{$\begin{array}{c}\text { Direct tiger } \\
\text { sighting (no) }\end{array}$} & $\begin{array}{c}\text { Roaring } \\
\text { heard } \\
\text { (no) }\end{array}$ & \multicolumn{2}{c|}{$\begin{array}{c}\text { Sighting of } \\
\text { fresh } \\
\text { pugmarks (no) }\end{array}$} \\
\cline { 2 - 6 } & Adult & Cub & & Adult & Cub \\
\hline April & 20 & - & 10 & 586 & 3 \\
\hline May & 16 & - & 8 & 629 & - \\
\hline June & 23 & - & 6 & 411 & - \\
\hline July & 20 & 4 & 5 & 380 & - \\
\hline August & 31 & - & 19 & 433 & 5 \\
\hline September & 17 & - & 19 & 332 & 1 \\
\hline October & 53 & - & 12 & 466 & 1 \\
\hline November & 37 & - & 17 & 455 & - \\
\hline December & 39 & - & 15 & 747 & - \\
\hline January & 51 & - & 22 & 849 & - \\
\hline February & 37 & 2 & 17 & 711 & - \\
\hline March & 50 & - & 6 & 540 & - \\
\hline Total & 394 & 6 & 156 & 6539 & 10 \\
\hline
\end{tabular}

The present survey, based on direct sighting and indirect evidences along the river/creek banks, bank-side mangroves and at the watchtower locations, revealed that the tigers were present throughout the landscape with varying abundance. In all, the tiger was sighted 417 times (mean 13 in September and maximum 56 in January) in fourteen forest blocks during the study period (Table 9). Such sighting was frequent during the winter and summer months. Maximum sighting was recorded on the north-western forest blocks like Pirkhali (43.16\%), Netidhopani (18.46\%), Arbesi (13.18\%) and Panchamukhani (5.75\%). Although tiger was not sighted in Mayadwip block, the pugmarks of a mother along with a cub and (separately) those of an adult male were traced in this island a number of times in May. 
Table 9: Month (M)-wise tiger sighting records in STR during 2010 survey

\begin{tabular}{|c|c|c|c|c|c|c|c|c|c|c|c|c|c|}
\hline Forest block & M1 & M2 & M3 & M4 & M5 & M6 & M7 & M8 & M9 & M10 & M11 & M12 & Total \\
\hline Panchamukhani & 1 & 1 & 1 & 4 & 1 & 2 & 1 & 2 & - & 3 & 2 & 6 & 24 \\
\hline Pirkhali & 33 & 31 & 23 & 27 & 9 & 10 & 16 & 4 & 3 & 3 & 5 & 16 & 180 \\
\hline Matla & 1 & 2 & 2 & 1 & 1 & 2 & 1 & - & - & - & - & - & 10 \\
\hline Chamta & - & - & 2 & 1 & 1 & - & 2 & - & - & - & - & 1 & 7 \\
\hline Chhotohardi & 3 & 1 & 1 & - & - & 1 & 2 & - & 1 & - & - & - & 9 \\
\hline Goasaba & 1 & - & 3 & 1 & 1 & - & 5 & 1 & 1 & 1 & - & 2 & 16 \\
\hline Gona & - & - & - & - & - & - & 1 & - & - & 1 & - & - & 2 \\
\hline Bagmara & - & 2 & - & 1 & - & - & - & - & - & - & - & - & 3 \\
\hline Mayadwip & - & - & - & - & - & - & - & - & - & - & - & - & 0 \\
\hline Arbesi & 2 & 2 & 6 & 1 & 4 & 4 & 9 & 3 & 6 & 5 & - & 13 & 55 \\
\hline Jhilla & 2 & 1 & 3 & 2 & 1 & - & 3 & - & - & 1 & - & - & 13 \\
\hline Khatuajhuri & 2 & 2 & 3 & - & 2 & - & 1 & 1 & - & - & 1 & 1 & 13 \\
\hline Harinbhanga & 1 & - & 1 & 1 & - & - & - & 1 & - & - & - & 1 & 5 \\
\hline Netidhopani & 10 & 4 & 11 & 11 & 4 & 11 & 3 & 5 & 2 & 10 & 1 & 5 & 77 \\
\hline Chandkhali & - & 1 & 1 & - & 1 & - & - & - & - & - & - & - & 3 \\
\hline Grand total & 56 & 47 & 57 & 50 & 25 & 30 & 44 & 17 & 13 & 24 & 9 & 45 & 417 \\
\hline
\end{tabular}

Four cubs were also sighted, two each at Pirkhali and Chhotohardi in November. However, the cubsighting ratio is very low in the study area. In all, only five cubs were found in three out of fifteen blocks (20\%). Earlier, the author found the signs of hunting a deer by the tiger at Burirdabri (Khatuajhuri block), opposite Bangladesh. There was a resident tiger family including a cub in this small island.

During the study, the tigers used different habitats for definite purposes like shelter, breeding, hunting, etc. This habitat use pattern vis-à-vis the forest types are recorded separately (Table 10). Out of thirteen forest types/associations, nine (88\%) are used as habitats (shelter $=72 \%$, breeding $=7 \%$ and hunting $=9 \%$ ) and four types (12\%) are not normally preferred by the tigers. Due to frequent shifting or island-migration and occupation of new habitat by the tigers, the habitat occupation and range of movement varies considerably from individual to individual and from time to time, mainly depending on availability of the prey species - be it wild, domestic or human beings entering forests with legal permits or illegally.

A review of the human-tiger conflict data showed only one case of tiger poaching during the twenty first century (Table 11). Moreover, the incidences of human deaths due to tiger depredation in the forests are also on the wane (Fig. 2). But tigerstraying cases have recently been increased greatly, particularly after the onslaught of cyclone Aila in 2009 (Table 12). The straying tigers were captured with the help of the villagers and committee members and rehabilitated in the wild. Similarly, a good number of other mammals were also rescued and rehabilitated (Table 13).

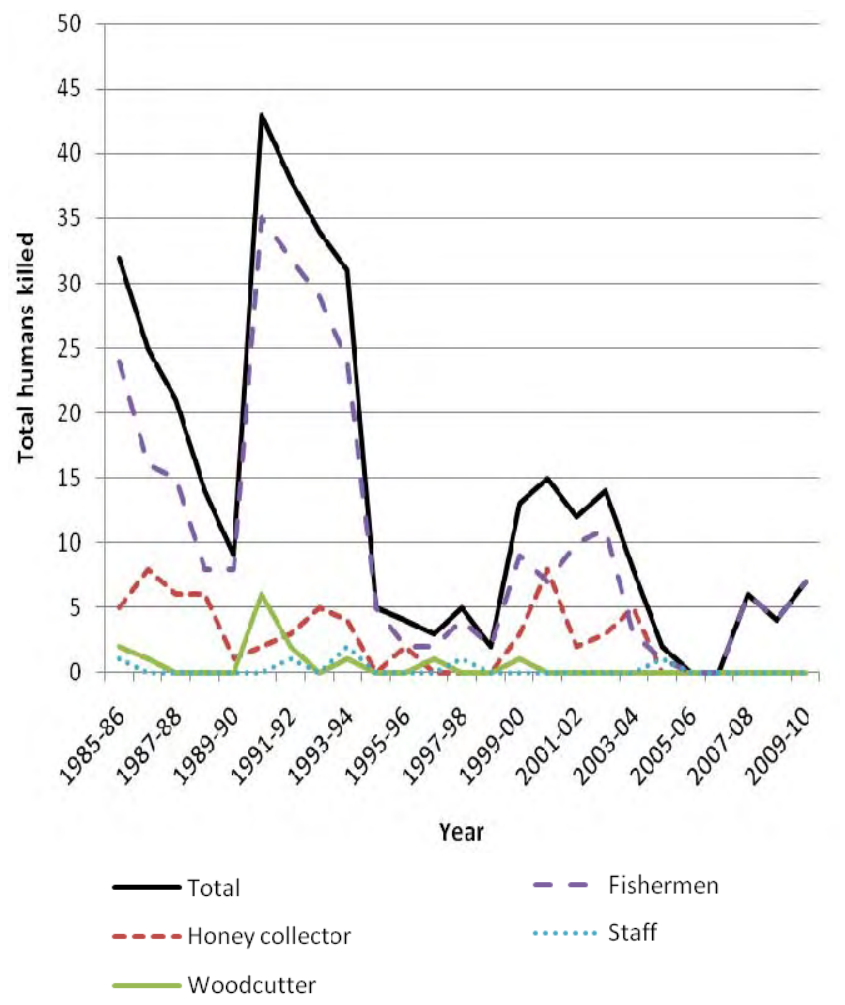

Fig. 2: Humans killed by tigers in Sundarban Tiger Reserve since 1985. 
Table 10: Habitat types used by tigers in STR

\begin{tabular}{|c|c|c|c|c|c|}
\hline Tide levels & $\begin{array}{c}\text { Type of habitat- Pure or } \\
\text { mixed }\end{array}$ & $\begin{array}{c}\text { Percentage of } \\
\text { total forests }\end{array}$ & $\begin{array}{c}\text { App. density of } \\
\text { trees/acre }\end{array}$ & $\begin{array}{c}\text { Abundance } \\
\text { indicators }\end{array}$ & Remarks \\
\hline High & $\begin{array}{l}\text { Coastal forests with } \\
\text { Casuarina spp. and others } \\
\text { bordered by high retaining } \\
\text { sand-wall }\end{array}$ & Very small & Variable & $\begin{array}{c}\text { Present in } \\
\text { good numbers }\end{array}$ & $\begin{array}{l}\text { Ideal breeding } \\
\text { site with } \\
\text { abundant preys; } \\
\text { e.g. signs of } \\
\text { mother-cub seen } \\
\text { at Mayadwip. }\end{array}$ \\
\hline \multirow{9}{*}{$\begin{array}{l}\text { Above } \\
\text { natural tidal } \\
\text { limits }\end{array}$} & $\begin{array}{c}\text { Heritiera-Phoenix } \\
\text { (submerged only a number } \\
\text { of times during kotals). }\end{array}$ & $2 \%$ & 5,000 & Common & $\begin{array}{l}\text { Ideal tiger } \\
\text { habitat }\end{array}$ \\
\hline & Heritiera-Excoecaria & $2 \%$ & $3,000-5,000$ & Presence low & Not ideal habitat \\
\hline & $\begin{array}{c}\text { Heritiera-Excoecaria- } \\
\text { Ceriops }\end{array}$ & $4 \%$ & $3,000-5,000$ & Presence low & Not ideal habitat \\
\hline & Exсоесаria-Phoenix & $3 \%$ & $3,000-5,000$ & Common & $\begin{array}{l}\text { Ideal tiger } \\
\text { habitat including } \\
\text { breeding }\end{array}$ \\
\hline & Phoenix & $4 \%$ & 3,000 & Common & $\begin{array}{l}\text { Ideal tiger } \\
\text { habitat including } \\
\text { breeding }\end{array}$ \\
\hline & Excoecaria & $2 \%$ & $200-300$ & Rare & Not ideal habitat \\
\hline & Ceriops & $5 \%$ & 500 & Visitor & $\begin{array}{l}\text { Ideal hunting } \\
\text { ground }\end{array}$ \\
\hline & Excoecaria-Ceriops & $70 \%$ & $\begin{array}{l}\text { Genwa: } 100- \\
400 \\
\text { Garan: } 500\end{array}$ & Common & $\begin{array}{l}\text { Ideal tiger } \\
\text { habitat }\end{array}$ \\
\hline & Rhizophora-Bruguiera & $4 \%$ & Not dense & Uncommon & Not ideal habitat \\
\hline \multirow[t]{3}{*}{$\begin{array}{l}\text { Below } \\
\text { natural tidal } \\
\text { limits }\end{array}$} & Oryza coarctata & Riverbanks & Average & Uncommon & $\begin{array}{l}\text { Hunting } \\
\text { (Cheetal) } \\
\text { ground, } \\
\text { particularly } \\
\text { April-June }\end{array}$ \\
\hline & Avicennia-Oryza & $2 \%$ & Average & Uncommon & - do - \\
\hline & Avicennia-Sonneratia & $2 \%$ & Average & Uncommon & - do - \\
\hline
\end{tabular}

Table 11: Natural death cases (ND) and poaching (P) of mammalian species in STR

\begin{tabular}{|c|c|c|c|c|c|c|c|c|c|c|c|c|}
\hline \multirow{2}{*}{ Name } & \multicolumn{2}{|c|}{ 2003-2004 } & \multicolumn{2}{|c|}{ 2004-2005 } & \multicolumn{2}{|c|}{ 2005-2006 } & \multicolumn{2}{|c|}{ 2006-2007 } & \multicolumn{2}{|c|}{$2007-2008$} & \multicolumn{2}{|c|}{ 2008-2009 } \\
\hline & $\mathrm{ND}$ & $\mathrm{P}$ & $\mathrm{ND}$ & $\mathrm{P}$ & ND & $\mathrm{P}$ & $\mathrm{ND}$ & $\mathrm{P}$ & ND & $\mathrm{P}$ & $\mathrm{ND}$ & $\mathrm{P}$ \\
\hline Tiger & 1 & - & - & - & 1 & - & 1 & - & - & - & - & 1 \\
\hline Fishing cat & 2 & - & 1 & - & 4 & - & - & - & 4 & - & - & - \\
\hline Jungle cat & 1 & - & - & - & 4 & - & - & - & - & - & - & - \\
\hline Cheetal & 10 & 1 & 2 & - & 10 & 2 & 3 & - & 3 & 4 & 2 & - \\
\hline Wild boar & - & - & - & 1 & 1 & - & 3 & 4 & 1 & - & - & - \\
\hline $\begin{array}{c}\text { Rhesus } \\
\text { macaque }\end{array}$ & - & - & - & - & - & - & 1 & - & 1 & - & - & - \\
\hline Dolphin & - & - & 1 & - & - & - & 2 & - & 1 & - & 1 & - \\
\hline Otter & - & - & - & - & - & - & - & - & - & - & 1 & - \\
\hline Mongoose & - & - & - & - & 1 & - & - & - & - & - & 1 & - \\
\hline
\end{tabular}

Table 12: Tiger straying incidents detected in STR

\begin{tabular}{|c|c|c|c|c|c|c|c|c|c|}
\hline Year & Number & Year & Number & Year & Number & Year & Number & Year & Number \\
\hline 1986 & 14 & 1987 & 20 & 1988 & 4 & 1989 & 4 & 1990 & 11 \\
\hline 1991 & 1 & 1992 & 3 & 1993 & 1 & 1994 & 8 & 1995 & 25 \\
\hline 1996 & 18 & 1997 & 3 & 1998 & 5 & 1999 & 10 & 2000 & 6 \\
\hline 2001 & 8 & 2002 & 26 & $2003-04$ & 23 & $2004-05$ & 14 & $2005-06$ & 2 \\
\hline $2006-07$ & 11 & $2007-08$ & 11 & $2008-09$ & 15 & $2009-10$ & 24 & & \\
\hline
\end{tabular}


Table 13: Rescue and release of mammalian species other than tiger in STR

\begin{tabular}{|c|c|c|c|c|c|c|}
\hline Name & $\mathbf{2 0 0 3 - 2 0 0 4}$ & $\mathbf{2 0 0 4 - 2 0 0 5}$ & $\mathbf{2 0 0 5 - 2 0 0 6}$ & $\mathbf{2 0 0 6 - 2 0 0 7}$ & $\mathbf{2 0 0 7 - 2 0 0 8}$ & $\mathbf{2 0 0 8 - 2 0 0 9}$ \\
\hline Fishing cat & - & 3 & 4 & 3 & 2 & 8 \\
\hline Jungle cat & 4 & 4 & 4 & 8 & 7 & 5 \\
\hline Leopard cat & - & - & - & 1 & 1 & - \\
\hline Civet cat & - & - & - & - & 2 & - \\
\hline Cheetal & 1 & 1 & 15 & - & 2 & - \\
\hline Wild boar & 1 & 4 & 6 & 50 & 6 & 6 \\
\hline Jackal & - & - & - & - & 1 & 1 \\
\hline Rhesus macaque & 1 & 1 & 1 & 3 & - & 5 \\
\hline Dolphin & 3 & - & - & - & & 1 \\
\hline $\begin{array}{c}\text { Small clawless } \\
\text { otter }\end{array}$ & - & - & 1 & 4 & & 1 \\
\hline Mongoose & - & - & - & 2 & & 1 \\
\hline
\end{tabular}

Shrinkage of habitat due to tides, salinity of creek waters and pneumatophore-infested forest floor have offered a very adverse habitat conditions for the tigers. Nevertheless, they were reportedly more or less present in all the fifteen blocks of STR since early 1970s and their predatory aberration was also reported as they used to migrate from block to block (Chamta-Matla to adjoining ChandkhaliNetidhopani-Panchamukhani-Pirkhali) (Chaudhuri \& Chakrabarti, 1980). But their abundance is variable in different blocks. Earlier, the tigeroccupancy in STR was reported to be $1,586 \mathrm{~km}^{2}$ (Jhala et al., 2008).

The Sundarban is a unique habitat (Vyas, 2005), where the tiger occupies the pinnacle of both the aquatic and terrestrial food web. While the males change their territory more, the females tend to hold a territory for comparatively longer periods. The territory of a male also overlaps the territories of more than one female. The cubs are reared exclusively by the mother and they remain attached to her for up to two and half years. The female cubs often occupy territories or home ranges adjacent to that of their mother. During the daily activity, every tiger records its presence while walking on soil amenable to receiving its pugmarks. While the tiger pugmarks were found along the banks of the creeks and rivers, their scats (wet as well as dry) were found at Harinbhanga 3, Jhilla 1, 2 and 3, Arbesi 5, Chandkhali 2 and 3, Bagmara 3 and 8, Chamta 4, Matla 3, Chhotohardi 3, Panchamukhani 5, Khatuajhuri 2, Mayadwip 1, Pirkhali 2 and also near the sweet water ponds visited by the tigers like Dobanki camp (Pirkhali 5), Sajnekhali camp (Pirkhali 1), Choragazi (Panchamukhani 3), Jhingakhali (Arbesi 1), Tushkhali (Khatuajhuri 1), etc. The nail marks (scratching) of some tigers on the trees like $X$. granatum (males), S. apetala and Avicennia spp. (females) were also observed. The tiger-roars were heard mostly between the premonsoon and the pre-winter, but rarely thereafter. These calls are generally related to the hunting, mating and sometimes while the mother moving with her cubs encounters an enemy.

The habitat pattern in STR is uniformly monotonous, not broken by such landscape features that are known to provide specific cover for the tiger in other areas. The Heritiera and Phoenix thickets, which are not either regularly inundated or inundated for a short period, form a favoured tiger's den and signs of its presence is commonly found in the plant consociations of Rizophora-Bruguiera, Avicennia-Oryzha, Excoecaria-phoenix, ExoecariaCeriops, pure Ceriops and pure Oryzha. The natural prey animals occupying the tiger niche are the cheetal, wild boar and rhesus monkey. During the study, the encounter rates of the cheetal was found to be high $\left(3.8 / \mathrm{km}^{2}\right)$ compared to those of the wild boar $\left(0.14 / \mathrm{km}^{2}\right)$ and rhesus macaque $\left(1.2 / \mathrm{km}^{2}\right)$. Large groups of the deer were seen on the higher grounds, which are generally not inundated during the high tides. The Rhesus monkeys were commonly found on the Keora (S. apetala) patches.

The secondary predators are mainly the fishing cat and, to a small extent, the jungle cat and leopard cat. The fishing cats dwell amidst the dense vegetation associated with the marshes and mangroves (Mallick, 2010a). The encounter rate of the fishing cat was $0.03 / \mathrm{km}^{2}$. The pugmarks of the leopard cat were distinguished from those of the fishing cats on the basis of absence of any nailimprint on the soil. Otters were rarely sighted (encounter rate $0.009 / \mathrm{km}^{2}$ ).

Among the dolphins, the Gangetic dolphin is frequently found in the eastern side, particularly in the river Raimangal, the upper part of which is fed 
by some freshwater flow. It descends during the monsoon season when salinity is low but appears to decrease in number during the summer (Mallick, 2011). This migration also seems to be associated with the migration and dispersal of fishes, which are their main prey. The Irrawaddy dolphins are not found in the more saline Matla-Hooghly estuary. Seventeen individuals were seen in the premonsoon and twenty two in the post-monsoon months. The Irrawaddy dolphins were recorded mostly in the lower reaches of the river Raimangal and a few were also observed at the Jhilla and Amlamati. There was no sighting record of this species in the river Matla, which is a habitat of the Ganges dolphin. The black finless porpoise were rarely found in the rivers near the estuary.

The Sundarban tiger exhibits certain distinctive morphological adaptations that make it particularly suited to the mangrove habitat (Barlow et al., 2010). Unlike the mainlanders, these islanders are much smaller (suggesting insular dwarfism), more muscular with leaner frame and lesser body mass $( \pm 100 \mathrm{~kg})$. The stress factor associated with changes in their natural habitat and the availability of the smaller prey species is often related to such phenomenon.

In the study area, two adult female and three adult male tigers were captured, radio-collared and released back into the forests. Of them, a six-year old male (Netidhopani tiger) was captured, while straying into inhabited areas, and weighed only 97 $\mathrm{kg}$. Its neck was measured $53 \mathrm{~cm}$ against the normal size of $65-75 \mathrm{~cm}$. Another adult tiger (Khatuajhuri male), which was caught at Malmelia village of Basirhat range, was also found to be frail and underweight $(108 \mathrm{~kg}$ ) with the neck-size of $58 \mathrm{~cm}$.

The natural prey animals of the Sundarban tiger are also smaller (e.g., the Cheetal, wild boar and rhesus monkey), compared to the heavier sambar or gaur in the mainland. It is assumed that a smaller islander needs lesser food. Less body weight enables it to move through the muddy terrain with minimum loss of energy, otherwise the feet of a heavy-weight tiger would sink deep into the muddy soil during its movement along the banks. Besides, these islanders are capable of leading an almost amphibious life unlike the mainland tigers. Besides, its prey species like the cheetal and wild boar are also semi-aquatic. The rhesus macaques were also found to migrate in search of food. Hence, the predator has to change their territory following its prey species.
Garga (1948) recorded a tiger swimming over 6 miles in the river Hooghly. There were records of tiger swimming more than $20 \mathrm{~km}$, negotiating from one island to another, crossing more than one river. A problem tiger, which was released in the southernmost limit of STR, came back to the capture area on the north by covering about $100 \mathrm{~km}$ and crossing a good number of channels within a month. Tigers were seen swimming at right angle parallel to the current and changing their course, when they felt disturbed. In April, a tiger swam of continuously in the morning for about three hours in the rivers Mayadwip and Bidya, before entering forests at a different location. The radio-collared tigers were recorded to cross, on the average, ten channels (mean width $25 \mathrm{~m}$ and maximum width $200 \mathrm{~m}$ ) per day. In STR, the tigers have been recorded to cross larger ( $>5 \mathrm{~km}$ width) channels as well. From the sighting records, it appears that the tigers move even during the daytime in an undisturbed area.

Apart from the long-stretch swimming, the tiger has adapted to changed food habits. An earlier study on the scats of the tiger at fifty three locations in STR has revealed that in addition to its natural terrestrial prey species like the cheetal $(32.35 \%)$, wild boar (38.23\%), rhesus macaque $(2.94 \%)$, its food included the fish (2.94), crab (4.41\%), water monitor lizard, Varanus salvator (7.35\%), turtles (1.47\%), fishing cat (1.47\%), birds (2.94\%) and Phoenix leaves (Sanyal, 1993 \& 1999c). The tigers also ate honey and, before breaking the combs, smeared themselves with mud to avoid the stings. Remains of the venomous snakes (Ophiophagus hannah and Naja naja) were also detected in the stomach of a dead tiger at Netidhopani, after onslaught of the Aila. In case of the man-eating within the forest areas, the victims were mostly fishermen. Only 5\% of the tigers were reported to be man-eaters (Sanyal, 1998). Its frequent straying into the villages for hunting the domestic animals often causes retaliatory killing by mobs.

In STR, the deer is the most important herbivore in terms of number and biomass and their grazing and browsing is the main factor in structure of the vegetation cover. The fodder grass is limited in STR and includes the Dhani grass (Porteresia coarctata) as well as patches of Saccharum spp. grown on the sea-facing mud flats, which are good grazing grounds for the deer, but except for the newly generated succulent tips, the remaining parts are untouched. However, the cheetals prefer the Keora leaves, fruits and buds and also leaves of the 
Baen, Genwa and Kankra. They were seen to stand erect on their hind legs and browse the Sonneratia leaves.

The Keora fruits and leaves are also liked by the rhesus monkeys. The succulent leathery leaves of other mangrove trees are also taken by them. During June-July, the monkeys throw fruits on the ground, which are consumed by the cheetals. The monkey troops also drop the twigs and leaves, which are eaten by the deer.

The habitat of the wild boar is the tangled mass of Garan, whose extensive breaks harbour the sounders. The freshwater ponds dug in the forests near the watch towers attract the deer, pigs and tigers. The monkeys, however, consume the dew drops from the leaves of Keora. Like the tigers, the rhesus macaques feed on hermit crabs to supplement their diet and for this purpose, they have even to dexterously manoeuvre their movements to avoid landing their feet on needlelike piercing pneumatophores, which speaks of their obligatory dependency on this diet.

The size of a tiger's home range depends on prey abundance and in case of the males, access to the estrus females. In the study area, the mean distance moved by the radio-collared tiger/tigress per day was found to be $4.64 \mathrm{~km}^{2}$, whereas the maximum distance covered/day was $13.5 \mathrm{~km}^{2}$. While following a tiger on the bank of the Nabanki khal, it was observed to move a distance of $1 \mathrm{~km}$ in ten minutes. A radio-collared tigress moved over a radius of c. $30 \mathrm{~km}^{2}$ during a week (Mallick, 2010b). However, it could move much faster while chasing its prey.

The total mangrove forests of India and Bangladesh, having a viable tiger population, can potentially share their gene pool. Migration of the tigers between these two segments was anticipated, but there was no proof in the past. But during 2010, evidence of such territorial shifting was known. The straying Khatuajhuri male, blind on the right eye with signs of territorial fights, which was captured on $20^{\text {th }}$ May, radio-collared and released in the nearby forests on $22^{\text {nd }}$ May, crossed the river Harinbhanga and strayed into the Bangladesh Sundarban, where it remained in the island of Talpati till his collar stopped functioning on $5^{\text {th }}$ August. Hence, no further information regarding its movement was available.

\section{Recommendations}

Saving the tigers is essential not only for the biodiversity protection but also to safeguard the national identity. Project Tiger authorities should take immediate steps to conserve and expand mangroves, while preventing the poaching. The government should also take stringent measures to curb the immediate threats of environmental degradations for long-term survival of the floral and faunal resources through habitat improvement programmes. High priority for conservation, further infrastructural development and effective joint forest management are essential for saving this last stronghold of the Bengal tiger in India. The real challenge is to implement the tiger action plan by reconciling the competing interests of the multiple stakeholders and regulating the heavy biotic pressure, while making a safe and healthy habitat for the tigers and other species in this unique landscape with active participation of the local communities.

\section{Acknowledgements}

I am grateful to the local field staff and officers of the forest department as well as the respondents to the questionnaire survey for helping this study. I am also indebted to Indranil Mitra for providing the G.I.S. map of the study area and Somnath Chakraborti for retrieving relevant data.

\section{Literature cited}

Bahuguna, N. C. and J. K. Mallick, 2004. Ungulates of West Bengal and its adjoining areas including Sikkim, Bhutan and Bangladesh. In Ungulates of India, ENVIS Wildlife Protected Areas, 7 (1): 219238.

Bahuguna, N. C. and J. K. Mallick, 2010. Handbook of the mammals of South Asia. Natraj Publishers, Dehra Dun: 541.

Banerjee, S., 2009. Effects of Aila on the mangroves. West Bengal, 40 (9 \& 10): 29-31.

Barlow, A. C. D., J. Mazók, I. U. Ahmad and J. L. D. Smith, 2010. A preliminary investigation of Sundarbans tiger morphology. Mammalia, 74 (3): 329-331.

Chakrabarti, K., 1979a. Sundarbans- A unique habitat for tiger- a scientific study. International Symposium on Tigers 1979- India: 141-145. 
Chakrabarti, K., 1979b. Ecology of Sundarbans tigers with particular reference to range of habitats and adaptability to changes. International Symposium on Tigers 1979- India: 146-150.

Chakrabarti, K., 1980. Successful tranquillization of a Sundarbans tiger. Tigerpaper, 7 (4): 10.

Chakrabarti, K., 1984a. The Sundarbans tiger. Journal of the Bombay Natural History Society, 81 (2): 459460.

Chakrabarti, K., 1984b. An eco-biometrical study on tiger in the estuarine eco-system of Sundarbans. Indian Forester, 110 (6): 540-549.

Chakrabarti, K., 1984c. Statistical ecology of Sundarbans tigers. Tigerpaper, 11 (3): 29-31.

Chakrabarti, K., 1986. Tiger (Panthera tigris tigris) in the mangrove forest of Sundarbans - an ecological study. Tigerpaper, 8 (2): 8-11.

Chakrabarti, K., 1992. Man-eating tigers. Darbari Prokashan, Calcutta: 142.

Chakrabarti, K., 1993a. An ecological review of otter in the mangrove ecosystem of Sundarbans (India). Tigerpaper, 20 (1): 19-21.

Chakrabarti, K., 1993b. Biodiversity of Sundarbans vis-à-vis behaviour of tiger. Proceedings of International Symposium on tigers, February 1993, India.

Chakrabarti, K. and A. B. Chaudhuri, 1973. Wildlife biology of the Sundarban forests: a study of the habit and habitat of the tigers. Bulletin of the Botanical Society of Bengal, 26 (1): 63-66.

Chakrabarti, K. and A. B. Chaudhuri, 1974. Human casualties from man-eating tigers can be reduced. Scince and Culture, 40: 207-210.

Chakrabarti, K. and A. B. Chaudhuri, 1977. A statistical approach to wild animal: Population analysis. Cheetal, 19 (1): 19-20.

Chakrabarti, K. and A. B. Chaudhuri, 1979. Ecology of the Sundarban tigers with a particular reference to range and habitat and adaptability to changes. Cheetal, 20 (2\&3): 3-15.

Chakrabarti, K. and A. B. Chaudhuri, 1985. Sundarbans tiger: why are they man-eaters? Science Reporter, 22 (4): 239-240, 256.
Chakrabarti, K. and A. B. Chaudhuri, 1986. Tiger in the mangrove forest of Sundarbans: an ecological study. Tigerpaper, 13 (2): 8-11.

Chakrabarti, K. and J. K. De, 2007. Irrawaddy dolphin in northern Sundarban. West Bengal, 49 (10 \& 11): 59-62.

Champion, H. G. and S. K. Seth, 1968. A revised survey of the forest types of India. Government of India Press, New Delhi: 404.

Chaudhuri, A. B., 2007. Biodiversity of mangroves. Daya Publishing House, New Delhi: 332

Chaudhuri, A. B. and K. Chakrabarti, 1972. Wildlife biology of Sundarban forests- observations on tigrs. Cheetal, 15 (1): 65-68.

Chaudhuri, A. B. and K. Chakrabarti, 1979a. A decade study on the behaviour pattern of tigers. Proceedings of the International Symposium of tiger of India: 119125.

Chaudhuri, A. B. and K. Chakrabarti, 1979b. Tiger and man- the Sundarban tiger as viewed by fisherman and others who eke out their livelihood from the area. International Symposium on Tigers- India: 129, 135.

Chaudhuri, A. B. and K. Chakrabarti, 1979c. An ecological reconnaissance of tiger habitat and conservation of forest and wildlife. International Symposium on Tigers- India: 193-207.

Chaudhuri, A. B. and K. Chakrabarti, 1979d. Project Tiger- A premier and intricate conservation project. Proceedings of International Symposium on Tiger: 262-264.

Chaudhuri, A. B. and K. Chakrabarti, 1980. Wildlife biology of Sundarban forests- further study on the habitat and behaviour pattern of Sundarban tiger. Proceedings of the Workshop on Wildlife Ecology, Dehradun: 27-33.

Chaudhuri, A. B. and K. Chakrabarti, 1989. Sundarbans mangrove. Surya Publication, Dehra Dun: 210.

Chaudhuri, A. B. and A. Choudhury, 1994a. Mangroves of the Sundarbans. Volume 1: India. IUCN, Bangkok, Thailand: 247.

Chaudhuri, A. B. and A. Choudhury, 1994b. Wildlife biology of Sundarban forests. Science and Culture, 40 (3): 93-99. 
Chaudhuri, A. B. and D. D. Sarkar, 2004. Project Tiger Reserves: Resource diversity, sustainability, ecodevelopment. Daya Publishing House, Delhi: 341.

Chowdhury, M. K. and P. Sanyal, 1985a. Some observations on man-eating behaviour of tigers of Sundarbans. Cheetal, 26 (3-4): 32-40.

Chowdhury, M. K. and P. Sanyal, 1985b. Man-eating behaviour in the tigers of Sundarbans. Environment and Ecology, 3: 243-248.

Chowdhury, M. K. and P. Sanyal, 1985c. Use of electroconvulsive shocks to control tiger predation on human beings in Sundarban Tiger Reserve. Tigerpaper, 12 (2): 1-5.

Das, A. K. and N. C. Nandi, 1999a. Fauna of Sundarban Biosphere Reserve. Envis Newsletter, 5 (12): 4-9.

Das, A. K. and N. C. Nandi, 1999b. Fauna of Indian Sundarbans Mangal and their role in the ecosystem. In: Guha Bakshi, D.N. et al. (Eds.) Sundarbans Mangal, Naya Prakash. Kolkata.

Das, C. S., 2002. Tiger attack in Sundarban: nature and victims. Banabithi, October: 30-39.

Das, C. S., 2003. Tiger straying hazards in Sundarban, causes and management. Banabibi Utsab Smaranika, Sundarban Development Board, Sundarban Affairs Dept, Govt. of WB.

Das, C. S., 2005a. Rampant tiger poaching in Sundarban, Indian Journal of Landscape System and Ecological Studies, 28 (1): 111-117.

Das, C. S., 2005b. Tiger straying hazards in Sundarban, West Bengal. Geographical Review of India, 67 (1): 80-87.

Das, C. S., 2009. Spatio-temporal study of the hazards induced by tiger attack in Sundarban. West Bengal. Indian journal of landscape System \& Ecological Studies, 32 (1): 330-338.

De, R. N., 1990. The Sundarbans. Oxford University Press, Calcutta: 75.

Dent, T. V., 1932. Tigers in the Sundarbans. Journal of the Bombay Natural History Society, 38 (1): 178179.

Deuti, K. and B. Roy Choudhury, 1999. Possible causes for the straying of tigers in the Sundarbans and some suggested remedies. In Sundarbans Mangal,
Guha Bakshi, D. N., P. Sanyal and K. R. Naskar (eds), Naya Prakash, Kolkata: 460-465.

Dwivedi, R., 2009. Tiger's day out. Banabithi: 20-21.

Garga, D. P., 1948. How far can a tiger swim? Journal of the Bombay Natural History Society, 47 (3): 545546.

Ghosh, A. and N. Mandal, 1988. Straying and abnormal behaviour of mating tigers of Sundarbans. Cheetal, 29 (2): 1-4.

Ghosh, A. K. (Ed.), 1995. Fauna of Tiger Reserve (Sundarbans, Manas, Palamau, Similipal). Fauna of Conservation Areas. 8. ZSI. Calcutta: 127.

Gopal, B. and M. Chauhan, 2006. Biodiversity and its conservation in the Sundarban mangrove ecosystem. Aquatic Sciences - Research across boundaries, 68 (3): 338-354.

Government of India (GOI), 2005. The report of the Tiger Task Force: Joining the dots. Ministry of Environment and Forests (Project Tiger), New Delhi: 206.

Gupta, A. C., 1966. Wildlife of lower Bengal with particular reference to the Sundarbans. West Bengal Forests. Forest Directorate. Government of West Bengal. Centenary Commemoration Volume. Calcutta.

Jhala, Y. V., R. Gopal, Q. Qureshi (Eds.), 2008. Status of tigers, co-predators and prey in India. TR 08/001. New Delhi: National Tiger Conservation Authority and Wildlife Institute of India, Dehra Dun: 164.

Mandal, A. K., 1964. The Behaviour of the Rhesus Monkeys (Macaca mulatta Zimmermann) in the Sundarbans. Journal of Bengal Natural History Society, 33 (1):153-165.

Mandal, A. K., 1981. The Norway rat, Rattus norvegicus reappears in the Sundarban area in West Bengal. Rodent Newsletter, 5: 1-2.

Mandal, A. K., 1990. Addition of the Fawn-coloured Mouse, Mus cervicolor Hodgson, 1845 [Rodentia: Muridae] in the fauna of Sunderbans in West Bengal, India. Records of Zoological Survey of India, 85: 363365.

Mandal, A. K. and N. C. Nandi, 1989. Fauna of Sundarban Mangrove Ecosystem West Bengal, India. Calcutta, Zoological Survey of India: 116. 
Mallick, J. K., 2010a. Endangered fishing cats in human dominated landscape. Environ, 10 (3): 40-43.

Mallick, J. K., 2010b. GPS tracking of the tigers in Sundarban Tiger Reserve. Annual Review '09-'10, West Bengal State Office, WWF-India: 21-22.

Mallick, J. K., 2011. The national aquatic animal Ganges dolphin. Environ, 11 (1): 54-60.

Mukherjee, A. K., 1975. The Sundarbans of India and its biota. Journal of the Bombay Natural History Society, 72: 1-20.

Mukherjee, A. K., 1980. Wildlife in the Sunderban, West Bengal. Proceedings of the Workshop on Wildlife Ecology: 123-127. Dehradun, January 1978. Ed. Director, ZSI. Calcutta.

Mukherjee, A. and S. Gupta, 1965. Habits of the rhesus macaque, Macaca mulatta (Zimmerman) in the Sundarbans, 24-Parganas, West Bengal. Journal of the Bombay Natural History Society, 62: 145-146.

Mukherjee, S., 2003. Tiger human conflicts in the Sundarban Tiger Reserve, West Bengal, India. Tigerpaper, 30 (2): 3-6.

Mukherjee, S., 2006. Rhesus monkey and chital in the Sundarbans. Banabithi, Wildlife Issue, October 2006: 33-35.

Mukherjee, S. and G. Tanti, 2001. Capture and release of a strayed tiger under the Sundarban Tiger Reseve area. Tigerpaper, 28: 18-20.

Naskar, K. and R. Mandal, 1999. Ecology and biodiversity of Indian mangroves. Daya Publishing House, New Delhi.

Raha, A. K. and B. K. Saha, 2004. A wonder that is Sundarban. Computronics, Kolkata: 88.

Rishi, V., 1988. Man, mask and maneater. Tigerpaper 15 (3): 9-14.

Rishi, V., 1993a. Tiger-proof energized fence in Sundarban Tiger Reserve. Proceedings of the International Symposium on tigers, India.

Rishi, V., 1993b. The challenges of the man-eater. Proceedings of the International Symposium on tigers, India.

Rookmaaker, L.C., 1998. Records of the Sundarban rhinoceros (Rhinoceros sondaicus inermis) in India and Bangladesh. Pachyderm, 24: 37- 45.
Saha, D., 1988. A study of the Sundarban Tiger Reserve. Environment and Ecology, 5: 430-434.

Sanyal, P., 1981. Sundarban Tiger Reserve- an overview. Cheetal, 22 (4): 5-8.

Sanyal, P., 1983. Mangrove tigerland: the Sundarbans of India. Tigerpaper, 10 (3): 1-4.

Sanyal, P., 1987. Managing the man-eaters in the Sundarbans Tiger Reserve of India- a case study. In: Tilson, R. L. and U. S. Seal (Eds.), Tigers of the world: the biology, biopolitics, management, and conservation of an endangered species. Noyes Publications, Park Ridge, NJ: 427-434.

Sanyal, P., 1990. Tiger prey in the Sundarbans. Cat News, 13: 2.

Sanyal, P., 1992. Sundarbans mangrove; wildlife potential and conservation. In Tropical Ecosystems: Ecology and Management, Singh, K. P. and J. S. Singh (Eds.), Wiley Eastern Limited, New Delhi: 309314.

Sanyal, P., 1993. Tiger's food in the Sundarbans. Environ, 1 (1): 43-44.

Sanyal, P., 1998. Maneaters of Sundarbans. Environ, 6 (1): 17-22.

Sanyal, P., 1999a. Sundarban- The largest mangrove diversity on globe. In Sundarbans Mangal, Guha Bakshi, D. N., P. Sanyal and K. R. Naskar (Eds.), Naya Prakash, Kolkata: 428-448.

Sanyal, P., 1999b. Man-eating tigers of Sundarbans. In Sundarbans Mangal, Guha Bakshi, D. N., P. Sanyal and K. R. Naskar (eds), Naya Prakash, Kolkata: 449454.

Sanyal, P., 1999c. Tiger-food in Sundarbans. Banabithi, Wildlife Special Issue, October: 10-12.

Sanyal, P., 2001. Maneating tigers of Indian Sundarbans. West Bengal, 43 (20): 27-32.

Seidensticker, J., R. K. Lahiri, K. C. Das and A. Wright, 1976. Problem tiger in the Sundarbans. Oryx, 13 (3): 267-273.

Vyas, P., 2004. Tiger straying in Indian Sundarban: mystery and management. Environ, 9 (1): 43-46.

Vyas, P., 2005. Sundarban Tiger Reserve- a mystique tiger kingdom. West Bengal, 47 (9): 25-29. 